DOI 10.37882/2500-3682.2021.12.18

\title{
НЕРАВЕНСТВО В УДОВЛЕТВОРЕНИИ ЖИЛИЩНОЙ ПОТРЕБНОСТИ СРЕДИ ЖИТЕЛЕЙ МЕГАПОЛИСА САНКТ-ПЕТЕРБУРГА
}

\section{INEQUALITY IN THE SATISFACTION OF HOUSING NEEDS AMONG RESIDENTS OF THE MEGAPOLIS OF ST. PETERSBURG}

\section{A. Muftakhova}

Summary: The relevance of the topic is due to the fact that the sociodynamics of the modern megapolis determines the role of stratification in the distribution of public goods, including housing needs.

The subject of the study. The main attention is paid to the problem of access to the satisfaction of housing needs in the megapolis, which is chosen as St. Petersburg, which most embodied the specific features of the Russian and European cities. It is concluded that it is necessary to correlate objective and subjective data of social inequality in the megapolis in meeting housing needs, in order to more accurately predict the development of social processes in the housing sector. The same conclusion is to justify the existence of the need for hard-to-reach and high-value real estate (housing) in the sociodynamics of the modern megapolis.

The scientific novelty is determined by the fact that the study of the problem of social needs is particularly relevant in the unstable socioeconomic situation in modern society, which creates a lack of equal opportunities in the ways of solving the housing issue. The social need underlying stratification is constantly taking on new forms, changing in content. Inequality in housing needs can create serious social problems that can be mitigated by a balanced and effective housing policy. The processes of transformation of the former housing structure that have begun urgently require a thorough study, primarily due to the increasing degree of social inequality.

Keywords: housing, social needs, housing needs, housing stratification, social inequality, megapolis, urban space, reproduction, social practices, social chances.
Муфтахова Альмира Нургалиевна

Старший преподаватель, Северо-Западный институт управления Российской академии народного хозяйства и государственной службы при Президенте РФ,

2. Санкт-Петербург msmalmira@yandex.ru

Аннотация: Актуальность темы обусловлена тем, что социодинамика современного мегаполиса предопределяет роль стратификации в распределении общественных благ, в том числе и жилищных потребностей.

Предмет исследования. Основное внимание в работе уделено проблеме доступа к удовлетворению жилищной нужды в мегаполисе, в качестве которого избран Санкт-Петербург, в котором в наибольшей степени воплотились специфические черты российского и европейского города. Сделан вывод о необходимости соотношения объективных и субъективных данных социального неравенства в мегаполисе при удовлетворении жилищных потребностей, в целях более точных прогнозов развития социальных процессов в жилищной сфере. Так же вывод состоит в обосновании существования потребности в труднодоступном и высокостоимостном недвижимом имуществе (жилье) в социодинамике современного мегаполиса.

Научная новизна определена тем, что изучение проблемы социальных потребностей особо актуализируется в условиях нестабильной социально-экономической ситуации в современном обществе, порождающей отсутствие равных возможностей в способах решения жилищного вопроса. Социальная потребность, лежащая в основе стратификации, постоянно приобретает новые формы, изменяется по содержанию. Неравенство в удовлетворении жилищных потребностей способно породить серьёзные социальные проблемы, смягчить которые возможно с помощью сбалансированной и эффективной жилищной политики. Начавшиеся процессы трансформации прежней жилищной структуры настоятельно требуют обстоятельного изучения, и прежде всего, в силу увеличения степени социального неравенства.

Ключевые слова: жильё, социальная потребность жилищная потребность, жилищная стратификация, социальное неравенство, мегаполис, городское пространство, воспроизводство, социальные практики, социальные шансы. родолжающийся процесс трансакции современных общественно-экономических отношений позволяет обратиться к объясняющей характеристике классического определения города, как замкнутого поселения (населённого пункта), основанного на рыночной системе хозяйствования, поскольку мысль М. Вебера о городе, как о поселении, в котором действует рынок [1, с. 337], поддерживалась всеми учёными урбанистами [2, с. 96]. Эта теоретическая позиция становится особенно актуальной в условиях маркетизации социальных институтов, потому как в границах социального пространства городской деятельности осуществляются многочисленные практики по созданию, сохранению и преумножению социального капитала, в его материальной и нематериальной форме, что значимо для оценки результатов его обращения при исследовании городской экосреды.

Для дальнейшего развития проблематики материала целесообразным представляется сослаться на тезисы датского социолога Г. Эспинг-Андерсена: «Современные социологи, кажется, теряют интерес к своей исторической «социал-демократической» миссии. Всеядная, берущаяся за всё подряд социология теперь все больше 
отдаляется от центральных «компромиссов», от механики капиталистических демократий. За постизмами в современных исследованиях потерян индустриальный подход, ведущий к эволюции модерна» [3, с. 245-246].

Видится, что в городской социологии стало больше М.М. Пришвина, а не Ч. Дарвина, больше «Лесной капели» и «Кладовой солнца», а не «Происхождения видов» с естественным отбором в «пищевой цепи» города. Из экологического подхода зонирования городской среды Р. Парка, Э. Бёрджеса, Л. Вирта ушла институционализация зоологических процессов человеческих отношений. В урбанистике сегодня изучается эстетика акупунктуры городского пространства, а не столкновение классов и социальные конфликты. Проекты развития велодорожек и идеи внедрения публичных библиотек вытеснили проблему сегрегации и неравенства доступа к социальному благополучию жителей городов. Образы и символы обладания благами стали важнее их производства и потребления. Так, Дж. Джекобс приводит пример социального конфликта жителей жилого массива в Восточном Гарлеме касательно газона, где травяное покрытие маскировало коммунально-бытовые проблемы жильцов в глазах ответственных служб. Зелёный газон создавал видимость порядка, достигаемого игнорированием или подавлением порядка подлинного, который борется за свое существование и удовлетворение своих нужд [4, с. 28-29]. В условиях постмодерна нормы благополучного жизнеобеспечения замещаются образами и символами их обладания, что характерно и для перенесения этих отношений в жилищную сферу.

По сути своей жильё (или жилище, как натурально его рассматривают) является местом обитания, а не просто бетонной коробкой городских домов, на сакральное значение которой указывал Ж. Бодрийяр [5, с. 49]. П. Бурдьё видел в нём социально квалифицированное физическое место, предоставляющее усредненные шансы для присвоения различных материальных и культурных благ и услуг, имеющихся в распоряжении в данный момент [6, с. 59]. По словам французского социолога, осуществление этой власти на социо-культурные блага и услуги происходит через господство над закреплением и признанием права владения местом жительства, реализованного физически в социальном пространстве.

Имеющее своё важное теоретическое значение, определение жилья как места обитания, как отличительной категории от места пребывания (спального места) наталкивается на трудности практической реализации при современной трансформируемой системе хозяйствования. Существующий дефицит комплиментарности (который не имеет логического объяснения) в отношениях между жителями городов (индивидуальных агентов и групп пользования социальных ресурсов городского пространства) и институционализированными органа- ми распределения социальных благ и услуг приводит к актуализации поиска иных значений, чем закреплённость признанности прав владения на место жительства. То есть при современной форме хозяйствования в его рыночных формах нормативность права собственника на распоряжение имуществом, пусть даже и недобросовестном, воспринимается выше в структурной иерархии общества, чем право пользования (порой более ответственного) результатами воспроизводства социальных благ этого имущества, что нарушает формальную логику узуфрукта (право пользования чужим имуществом).

Например, арендатор или наниматель, реализовавший своё дарованное государством право в удовлетворении жилищной нужды на коммерческом рынке аренды жилья, оказывается в ловушке. С одной стороны, он является пользователем социальных благ, имеющих материальное воплощение в виде коммунально-бытовых услуг (тепло, вода, электричество), здоровьесберегающих служб (поликлиники, больницы), жизнеподдерживающих источников (продуктовые магазины, рынки), образовательных сервисов (школы, институты), а с другой - он не имеет нормативно-закреплённого права признания своего физически локализованного места жительства. Причина кроется в том, что истинный владелец жилья (нормативно-признанный собственник), находясь под влиянием спекулятивной модели рыночного поведения, поддерживаемой риэлторским сообществом, не заключает договоров с арендатором или нанимателем, а если и заключает, то на краткий негодичный срок (11 месяцев), пытаясь уйти от налогового бремени.

Наряду с этим, и устоявшиеся органы управления в рамках своих полномочий не имеют возможности учитывать конечного пользователя социальных благ, так как локально-занимаемое место обитания, является реципиентом материальных продуктов и бытовых услуг, физически потребляя их, но нормативной регистрации не происходит ввиду сокрытия факта наступления временного владения жильём.

В современной, находящейся в стадии трансформации, форме хозяйствования, выраженной в затянувшемся переходе от социального государства к капиталистическому строю, признаются сакраментальными собственнические отношения. Хотя в объективной реальности экономических практик воспроизводства и потребления материальных социальных благ, становится важным поиск добросовестного, ответственного пользования ими. В частности, иное высокостоимостное имущество, способное поспорить в ценности и значимости с недвижимостью, к примеру, автомобиль, облагается совокупностью норм и правил по пользованию и владению, порой имеющих (при невозможности решить данный вопрос) прямую рецепцию зарубежного опыта. Объяснение видится в доступности демон- 
стративного потребления символического значения вещественных доказательств обладания социальным статусом. Стереотипность (переходящая в стигматизм) восприятия обществом (сообществом индивидов) социального положения владельца люксового автомобиля, его классовой принадлежности, несравнима с общепринятыми штампами относительно собственников равноценного имущества, несмотря на падение реальной стоимости (на 20\%) транспортного средства в первый год его владения.

В случае с жилищем имеет место возникновение обрядовости, ритуальности, некой интимности, уводящей от мысли о господстве на владение социально-культурным благополучием к вопросам бытования, образе жизни, способах воспроизведения социального опыта в результате своей социализации. При том, что агенты потребления жилья, абоненты объектов недвижимости не могут адекватно оценивать личную власть на право пользования социальными благами, находясь в структурированном локальном пространстве внутри своего габитуса, и подвергаясь внешнему ментальному воздействию «чар» (магии и волшебству товарного фетишизма) института частной собственности. И здесь габитус, производящий восприятие права собственности, является порождающим принципом объективно классифицируемых практик и одновременно системой классификации этих практик, формируя представление о социальном мире или пространство стилей жизни [7, с. 26], путём институционализации ожиданий своего нормативного признания.

Действительно, сохраняющееся неравенство в жилищной сфере, отчасти порождается неспособностью регуляторов распределения социальных благ на жильё достичь параметров индустриальной эпохи (Рис. 1).

Как свидетельствуют данные, представленные на Рис. 1, когда происходит рост доходов граждан и улучшение демографических показателей, спрос на социальную реализацию естественных прав на жильё для населения не гарантирован как со стороны органов управления, так и со стороны самого жилищного строительства, как института. Казалось бы, на пик уверенности в будущем (период 2013-2014 гг.) пришелся спад в обеспечении площади жилых помещений, приходящейся в среднем на одного жителя, числа квартир и среднего размера квартир.

Стабильный характер неравенства демонстрируют данные по распределению домашних хозяйств по размеру общей площади жилища в среднем по децильным группам населения (Рис. 2).

Социальная направленность нормы определения квадратуры метров на человека отличает её от учетной нормы, нормы предоставления, санитарной нормы в 9-13 кв.м. Но функционирующая ограничительная мера в 18 кв.м. (для каждого члена семьи, состоящей из двух и более человек) при заключении договоров найма жилого помещения позволяет применить её определяющей в необходимом минимуме площади для проживания, а в дальнейшем и расширить до потребительского минимума в 33 кв.м. Так, из данных, представленных на Рис. 2, можно наблюдать, что недостаток социальной нормы жилья (18-20 кв.м.) затрагивает с первой $(70,4 \%)$ по пятую (40,5\%) децильные группы населения. И даже в десятой децильной группе наблюдается 25,1\% в 2017 г., 26,9\% в 2018 г. и 25,8\% в 2019 г. членов домохозяйств, вынужденных быть ограниченными проживанием в жилищах, не превышающих квадратуры социальных норм.

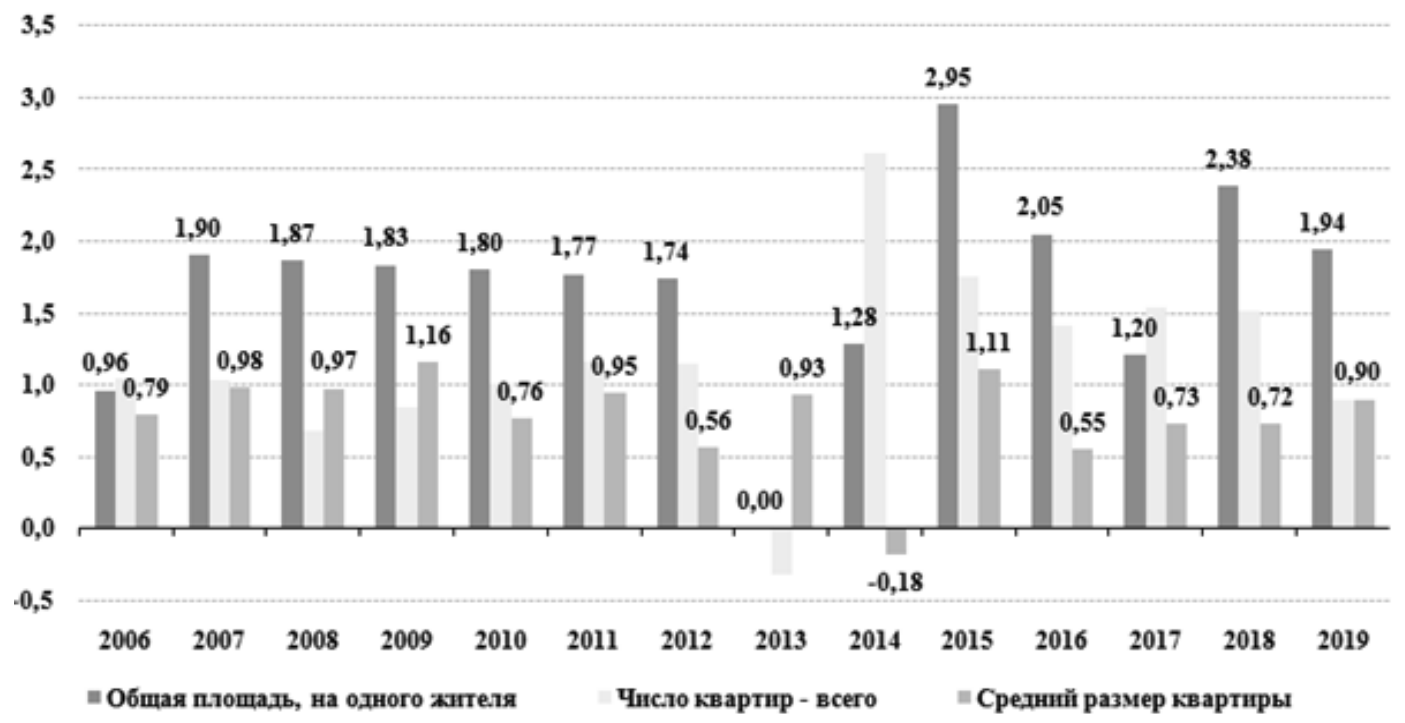

Рис. 1. Темпы роста ключевых показателей жилищных условий населения РФ к предыдущему году в динамике 2006-2019 гг. в относительном значении, \% (расчёт по данным Росстата [8]) 


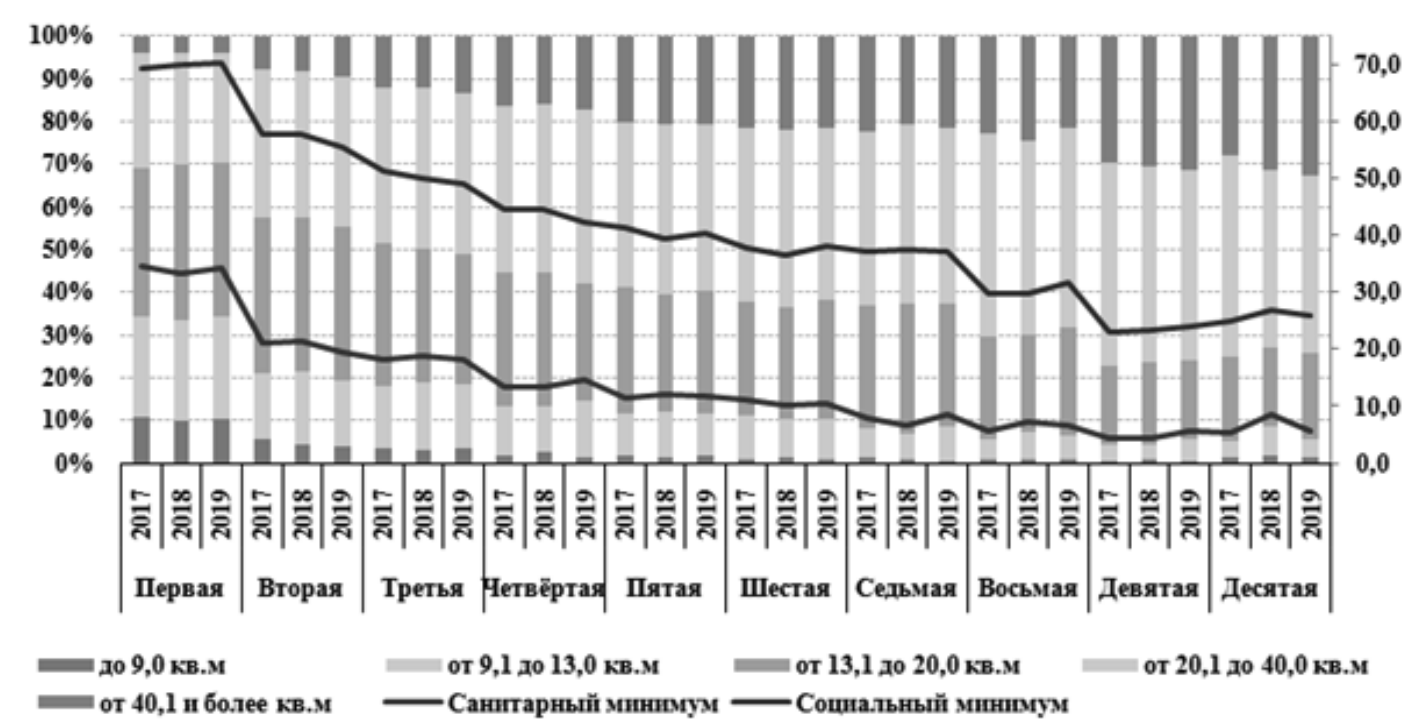

Рис. 2. Соотношение распределения домашних хозяйств по размеру общей (полезной) площади жилища в среднем на проживающего, в зависимости от уровня среднедушевых располагаемых ресурсов, по 10-ти процентным (децильным) группам населения в динамике 2017-2019 гг., \% (расчёт по данным Росстата [8])

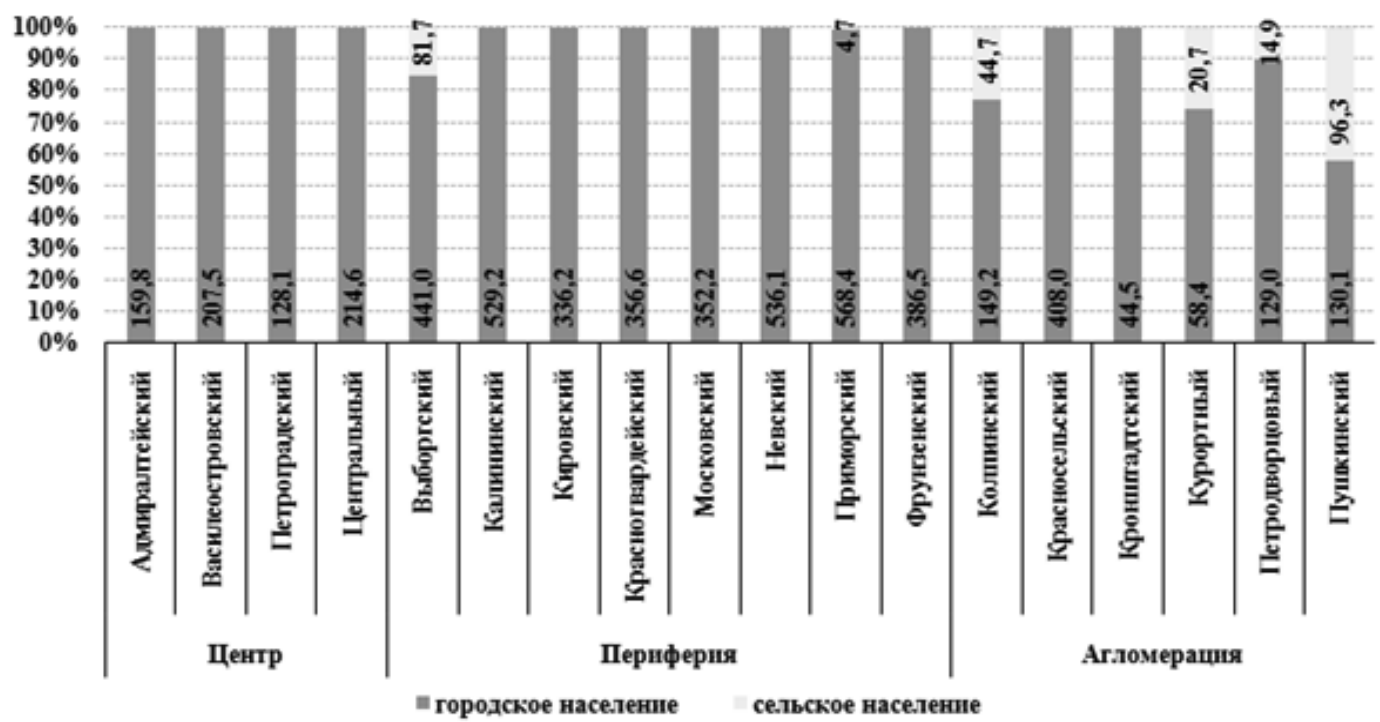

Рис. 3. Центрифирийность районов в городском пространстве мегаполиса Санкт-Петербурга, (составлено на основе данных Петростата [9] на 2020 г.)

В то же время степень удовлетворённости жилищными условиями современного большого города, мегаполиса также не отражает реальной картины.

В представленном материале, исходя из неовеберианского, классового и структурно-функционального подхода, г. Санкт-Петербург рассматривается как мегаполис. С позиции неовеберианского подхода, мегаполис анализируется как структурообразующий механизм концентрации: контроля над экономическими ресурсами, нормативном владении собственностью и коллективным действием по обладанию рыночными позициями (marketability). В результате имеем сово- купность бюрократических (иерархичных) отношений по управлению разностями хозяйствования в одном городском пространстве. С опорой на классовый подход, мегаполис Санкт-Петербург трактуется как глобальный город, включённый в транзитивный процесс сохранения и воспроизводства капитала в его материалистической форме. Итогом центрифирийности (centriphery) отношений борьбы за ресурсы и экономическое доминирование становится отнесение города к периферии капиталистических метрополий. С точки зрения структурно-функциональной теории (функционализма) и принципов территориальности, мегаполис представлен как совокупность единого ло- 
кального городского пространства (крупного города многомиллионника) и его агломерации, состоящей из 9 городов и 21 посёлка (Рис. 3).

Однако, подавляющее большинство населения мегаполиса некритично относится к жилищным условиям, и склонно воспринимать их скорее нейтрально, нежели резко позитивно или негативно. Здесь следует обратиться к анализу объективных данных «Итогов комплексного наблюдения условий жизни населения СанктПетербурга» [10] (Рис. 4).
Как можно наблюдать из данных Рис. 4, субъективное восприятие состояния скученности, стеснённости жилищных условий горожан не соответствует реальной обстановке, когда только 49,4\% седьмой децильной группы населения реалистично воспринимают объективный существующий недостаток необходимых для жизни социальных норм площади жилья. Предположим, что подобная анергия (толерантность) жителей мегаполиса порождается своеобразной пауперизацией (под пауперизацией понимаем устойчивую бедность, социальную болезнь, описанную П.Ж. Прудоном [11, с. 204]) (устойчи-

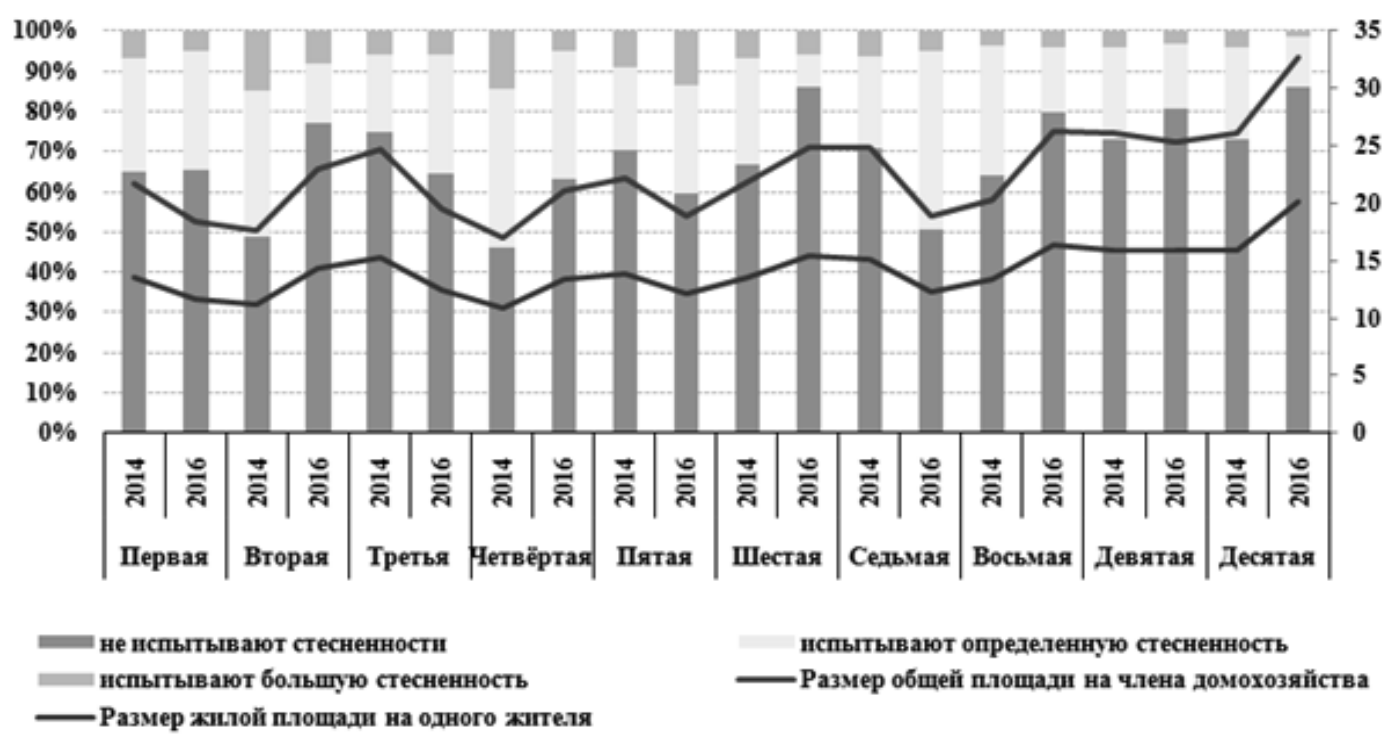

Рис. 4. Оценка жилищных условий населения Санкт-Петербурга, в том числе указавшие, что при проживании испытывают состояние скученности, в зависимости от уровня среднедушевых располагаемых ресурсов, по 10-ти процентным (децильным) группам населения в динамике 2014-2016 гг., \% (расчёт по данным Петростата [10; 9])

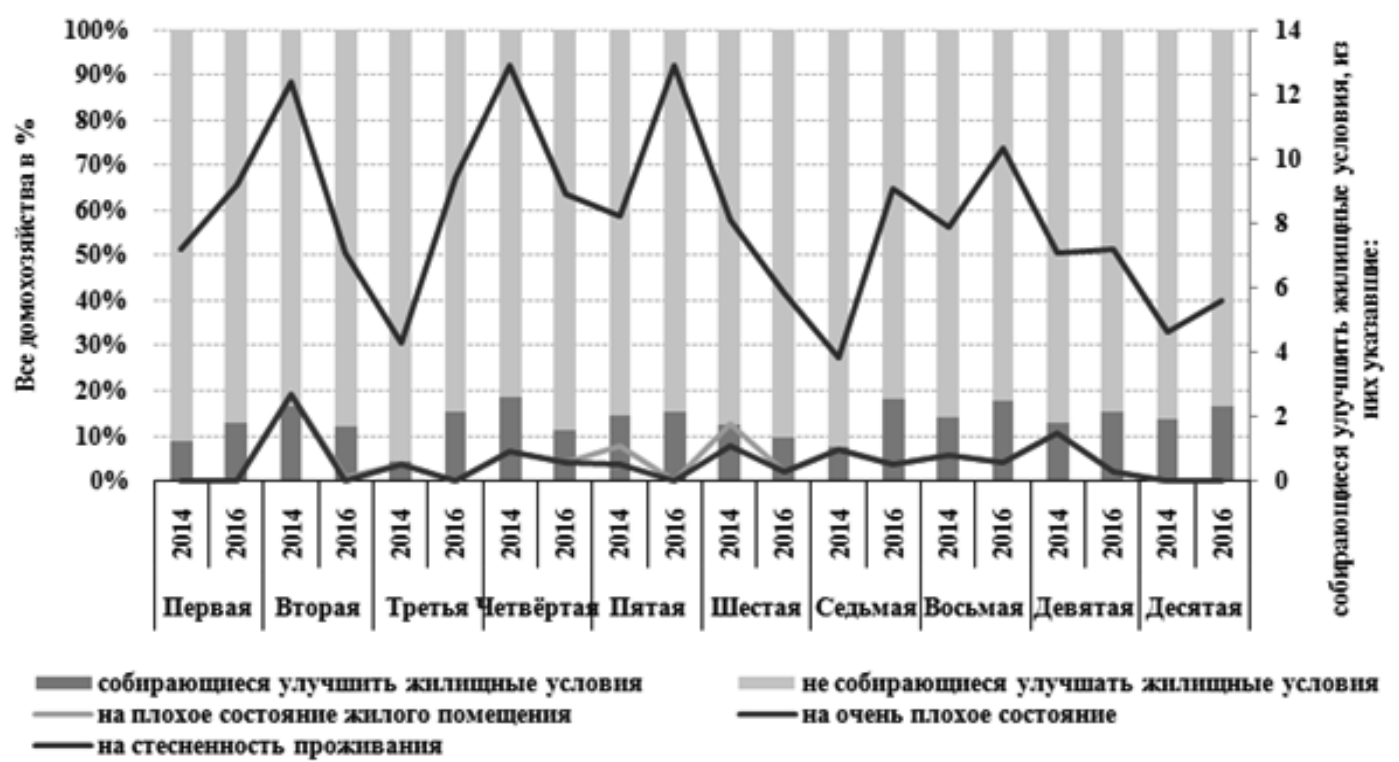

Рис. 5. Сравнение намерений населения Санкт-Петербурга улучшить свои жилищные условия и степени удовлетворенности ими, в зависимости от уровня среднедушевых располагаемых ресурсов, по 10-ти процентным (децильным) группам населения в динамике 2014-2016 гг., (расчёт по данным Петростата [9]) 
вой материальной депривацией) в удовлетворении жилищной нужды, лишением шанса в доступе к присвоению различных материальных и культурных благ и услуг, связанных с местом обитания.

Тем более, как показано на Рис. 5, основную рефлексию горожане, стремящиеся улучшить свои жилищные условия, испытывают в отношении стеснённости и скученности проживания, и данный критерий выделяется всеми децильными группами. На втором месте стоят вопросы (ими задаются с седьмой по девятой децильные группы горожан) состояния жилого помещения, что позволяет отметить низкий уровень самооценки своего места обитания, указывает на отсутствие требовательности к качеству жилища. Фактор аварийного состояния жилья волнует только четвёртую, седьмую и восьмую децильные группы населения Санкт-Петербурга.

Отсюда следует вывод, что индивиду свойственно приспосабливаться к жизненным условиям, воспроизводя количественные и качественные характеристики своего габитуса. «Любые поведенческие практики горожанина лежат на пересечении экономических, социальных, культурных, градостроительных сфер функционирования городского организма» [12, с. 300]. И это, в принципе, соответствует идее А. Шюца, согласно которой соотношение субъективного восприятия с объективной реальностью представляется в виде эллиптического выражения «S = p», где человек, находящийся в структурировано-детерминированной ситуации, объект «S» определяет через специфическое свойство «р», игнорируя другие показатели «q» и «r», как не имеющие своей значимости в естественной установке повседневной жизни [13, с. 12].

Таким образом, построение грамотных выводов при проведении исследования, опираясь только на субъективное восприятие объективной реальности, не пред-

\section{ставляется возможным.}

В качестве пояснительной характеристики распределения жилой недвижимости может быть использован термин «поглощение», предложенный Г.М. Стерником [14, с.140], как объяснительную функцию периферизации (peripheralized) экономической деятельности в метаболистической концепции мегаполиса О.Н. Яницкого $[15$, с. 16]. Однако, не отрицая важность учёта личной перцепции, считаем дополняющим компонентом при поиске добросовестного, ответственного пользования процессов воспроизводства и потребления материальных и социо-культурных благ и услуг в жилищной сфере исследование символов-знаков, характеризующих факторы удовлетворения жилищных условий, минимизирующих издержки и максимизирующих полезность жилья как места обитания.

\section{Выводы}

Считаем, что находясь в городском социальном пространстве, индивид, становясь актором конкурентных отношений по минимизации дистанции доступа к социо-культурному и имущественному благополучию, локально закреплён к физическому месту, образующему право претендовать на определяемый существующей хозяйственной системой набор социальных благ, и детерминируемый его габитусом.

Таким образом, фактическое использование материальных продуктов и бытовых услуг в месте обитания актуализирует вопрос о грамотном и добросовестном абоненте жилища. А поскольку общественный порядок признания господства на воспроизводство и потребление жилищных благ ограничен завышенными ожиданиями (очарованием) от института частной собственности, требуется проведение взвешенных исследований для установления конечного ответственного пользователя жильём.

\section{ЛИТЕРАТУРА}

1. Вебер М. История хозяйства. Город / М. Вебер; Пер. с нем.; Под ред. И. Гревса; Коммент. Н. Саркитова, Г. Кучкова. - М.: КАНОН-пресс-Ц, Кучково поле, 2001. -576 c.

2. Вирт Л. Избранные Работы по социологии. Сборник переводов / Л. Вирт; РАН ИнИОН. Центр социальных научно-информационных исследований. Отдел социологии и социальной психологии; Пер. с англ. Николаев В.Г.; Отв. ред. Гирко Л.В. - М.: ИНИОН, 2005. - 244 с.

3. Эспинг-Андерсен Г. Два общества, одна социология и никакой теории / Г. Эспинг-Андерсен // Журнал исследований социальной политики. - 2009 . - № 6 (2). - С. 241-266.

4. Джекобс Дж. Смерть и жизнь больших американских городов / Дж. Джекобс; Пер. с англ. - М.: Новое издательство, 2011. - 460 с.

5. Бодрийяр Ж. К критике политической экономии знака / Ж. Бодрийяр; пер. с фр. Д. Кралечкин. - М.: Академический Проект, 2007. - 335 с.

6. Бурдьё П. Социология социального пространства / П. Бурдьё; Пер. с франц.; отв. ред. перевода Н. А. Шматко. - М.: Институт экспериментальной социологии; СПб.: Алетейя, 2007. - 288 с.

7. Бурдьё П. Различение: социальная критика суждения / П. Бурдьё // Экономическая социология. - 2005. - Т. 6. - № 3. - С. 25-48.

8. Федеральная служба государственной статистики (Росстат) [Электронный ресурс] / Официальный сайт. - Режим доступа: http://www.gks.ru/ (дата 0бращения: 05.04.2021).

9. Управление Федеральной службы государственной статистики по г. Санкт-Петербургу и Ленинградской области (Петростат) [Электронный ресурс] / 
Официальный сайт. - Режим доступа: https://petrostat.gks.ru/ (дата обращения: 05.04.2021).

10. Итоги комплексного наблюдения условий жизни населения Санкт-Петербурга: Статистический бюллетень. - СПб.: Петростат, 2018. - 73 с.

11. Прудон П.Ж. Что такое собственность? или Исследование о принципе права и власти; Бедность как экономический принцип; Порнократия, или Женщины в настоящее время / П.Ж. Прудон; Подгот. текста и коммент. В.В. Сапова. - М.: Республика, 1998. - 367 с.

12. Еремичева Г.В. Градостроительная политика освоения социального и территориального пространств советского и российского города / Г.В. Еремичева // Социальные и пространственные измерения современного мегаполиса. Материалы IX социологических чтений памяти В.Б. Голофаста, 3-5 апреля 2017 г. - СПб.: Норма, 2017. - С. 298-319.

13. Шюц А. Избранное: Мир, светящийся смыслом / А. Шюц; пер. с нем. и англ., общ. и науч. ред., послесл. Н.М. Смирновой. - М.: РОССПЭН, 2004. - 1055 с.

14. Стерник С.Г. Методика прогнозирования объемов ввода на локальном рынке строительства и продажи жилья / С.Г. Стерник, Г.М. Стерник // Жилищные стратегии. - 2018. - Т. 5. - № 2.- С. 137-152.

15. Яницкий О.Н. Глобализация. Город. Человек: [монография] / 0.Н. Яницкий; предисл. Л.М. Дробижевой. - М.: ФНИСЦ РАН, 2018. - 177 с.

(c) Муфтахова Альмира Нургалиевна (msmalmira@yandex.ru).

Журнал «Современная наука: актуальные проблемы теории и практики»

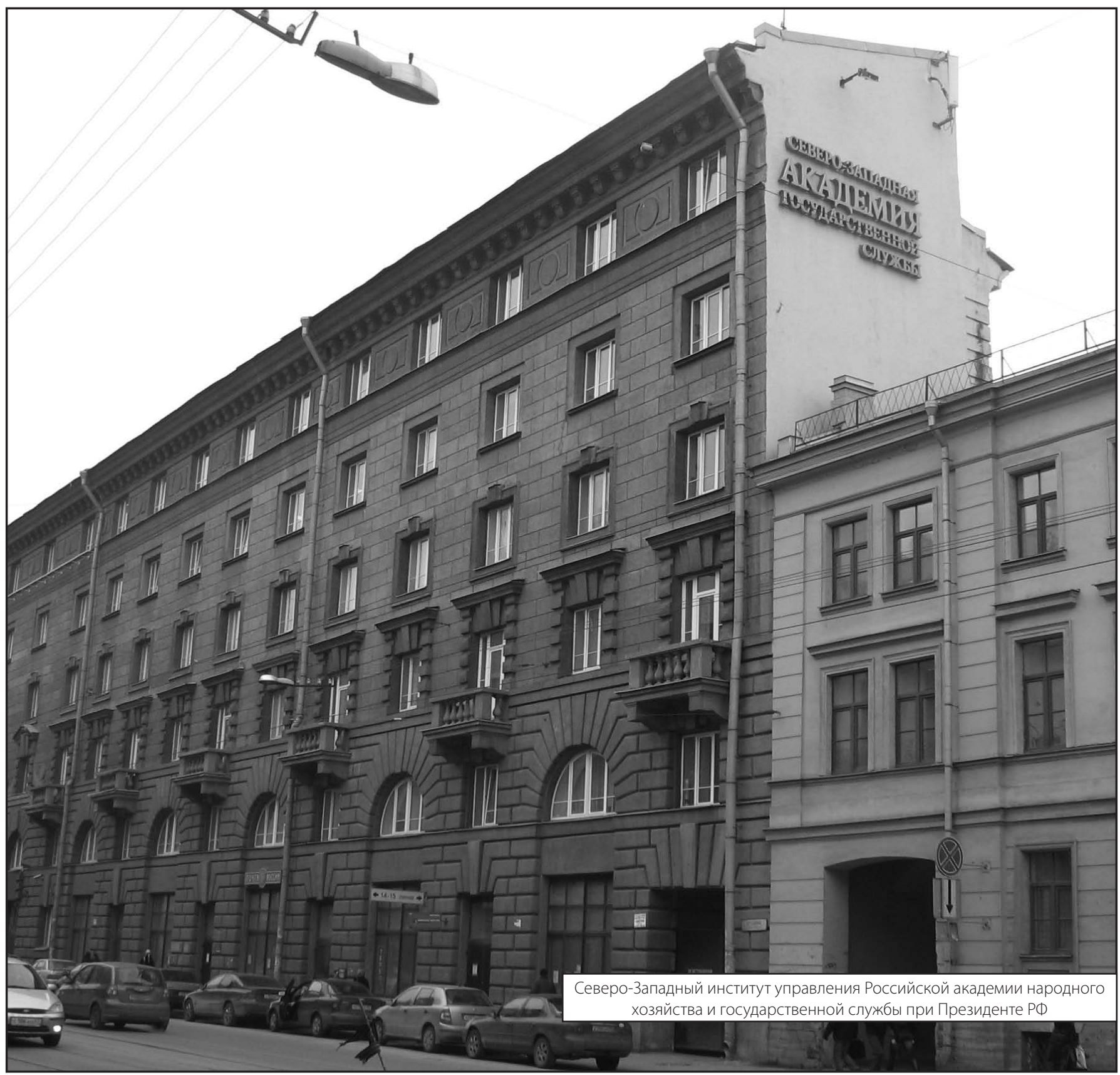

